\title{
Repeatability of cellular and soluble markers of inflammation in induced sputum from patients with asthma
}

\author{
J.C.C.M. in 't Veen, H.W.F.M. de Gouw, H.H. Smits, J.K. Sont, \\ P.S. Hiemstra, P.J. Sterk, E.H. Bel
}

Repeatability of cellular and soluble markers of inflammation in induced sputum from patients with asthma. J.C.C.M. in 't Veen, H.W.F.M. de Gouw, H.H. Smits, J.K. Sont, P.S. Hiemstra, P.J. Sterk, E.H. Bel. (OERS Journals Ltd 1996.

ABSTRACT: Sputum induced by inhalation of nebulized hypertonic saline is increasingly used to monitor airways inflammation in asthma. The aim of this study was to assess the repeatability of measuring cellular and soluble markers of inflammation in whole sputum samples as obtained by sputum induction in patients both with mild and moderate-to-severe asthma.

Twelve patients with mild, atopic asthma without inhaled steroid treatment and nine patients with moderate-to-severe, atopic asthma treated with inhaled steroids were studied on two separate days at least 2 days apart. Whole sputum samples, induced by inhalation of hypertonic $(4.5 \%)$ saline, were homogenized, and analysed for differential cell counts and for concentrations of albumin, fibrinogen, interleukin-8 (IL-8), and eosinophil cationic protein (ECP). Repeatability was expressed as intraclass correlation coefficient $(R i)$, and as coefficient of repeatability $\left(C_{R}\right)$ in percentage cells or in doubling concentration.

Samples from two patients with mild asthma contained more than $80 \%$ squamous cells and were excluded from analysis. The repeatability for cell differential counts in both groups combined was: for neutrophils, $R_{i}=0.57$ and $C_{R}=31.0$; for eosinophils, $R_{i}=0.85$ and $C_{R}=12.4$; and for lymphocytes, $R_{i}=0.76$ and $C_{R}=6.9$. The repeatability of the fluid phase measurements was: for albumin, $R i=0.71$ and $C_{R}=3.2$; for fibrinogen, $R i=0.88$ and $C_{R}=2.8$; for $I L-8, R i=0.66$ and $C_{R}=2.2$; and for $E C P$, $\mathrm{Ri}=0.82$ and $\mathrm{C}_{\mathrm{R}}=1.1$.

We conclude that the repeatability of cellular and soluble markers of inflammation in induced sputum from patients with mild and moderate-to-severe asthma is satisfactory. Hence, induced sputum, processed by using the whole expectorated sample, seems to be a valuable method to monitor airway inflammation in asthma. Eur Respir J., 1996, 9, 2441-2447.
Lung Function and Biochemistry Laboratories, Dept of Pulmonology, Leiden University Hospital, Leiden, The Netherlands.

Correspondence: J.C.C.M. in 't Veen Lung Function and

Biochemistry Laboratories

Dept of Pulmonology

Leiden University Hospital

P.O. Box 9600

2300 RC Leiden

The Netherlands

Keywords: Asthma

induced sputum

inflammation

reproducibility

Received: January 311996

Accepted after revision June 251996

This study was supported by a grant from Glaxo-Wellcome, The Netherlands.
In 1992, PIN et al. [1] first described the inhalation of nebulized hypertonic saline as a technique to induce sputum for studying airways inflammation in asthma. Since then, many efforts have been made to validate this technique [1-6]. Sputum induction is now being recognized as an inexpensive, easy to perform, well-tolerated, noninvasive, and safe method to monitor airways inflammation in asthma [7]. Several investigators employ the so-called "plug" or "selected sample" method [1-3, 6, 8], whereas others favour the analysis of whole sputum samples $[4,5,9,10]$. A major potential problem in the analysis of whole sputum samples is variable oropharyngeal contamination, potentially affecting the levels and reproducibility of various markers of inflammation.

The aim of this study was to assess the repeatability of measurements of cellular and soluble inflammatory markers in whole sputum samples induced by inhalation of nebulized hypertonic saline in patients with asthma. Differential cell counts in induced sputum were determined, and albumin and fibrinogen were measured as possible markers of capillary leakage [9], the chemokine interleukin-8 (IL-8) as a chemoattractant for neutrophils and primed eosinophils [11] and eosinophil cationic protein (ECP) as a toxic eosinophilic degranulation product $[9,12]$. Because the production and content of sputum might be influenced by disease severity and/or the presence of anti-inflammatory treatment, two groups of subjects were studied separately: one group of patients with mild asthma, treated only with short-acting $\beta_{2}$-agonists on demand; and another group of patients with moderate-to-severe asthma, all receiving regular inhaled corticosteroid therapy.

\section{Methods}

\section{Subjects}

Twelve subjects ( 5 females and 7 males) with mild atopic asthma, aged 18-26 yrs, and 9 subjects (6 females and 3 males) with stable, moderate-to-severe atopic asthma, aged 21-47 yrs, participated in the study. All subjects had a history of episodic dyspnoea and wheezing. 
Classification of asthma severity was based on history, symptoms, clinical features and requirement for medication according to the international guidelines [13]. Atopic status was verified by skin-prick test, with a wheal of at least $3 \mathrm{~mm}$ to one or more common airborne allergens (Soluprick; ALK, Denmark). All subjects were nonsmokers or ex-smokers (for more than 12 months, with less than 5 pack-years). The forced expiratory volume in one second (FEV1) was within the normal range ( $>80 \%$ of predicted) at baseline, or after inhalation of $400 \mu \mathrm{g}$ salbutamol by metered dose inhaler connected to an aerosol chamber [14]. In addition, all subjects were hyperresponsive to inhaled histamine as shown by a provocative concentration causing a $20 \%$ fall in FEV1 (PC20) of less than 8 $\mathrm{mg} \cdot \mathrm{mL}^{-1}[15]$.

All subjects were treated with inhaled short acting $\beta_{2^{-}}$ agonists on demand. The subjects with moderate-tosevere asthma also required regular therapy with inhaled corticosteroids (beclomethasone dipropionate or budesonide $200-1,000 \mu \mathrm{g}$ b.i.d.). They were asked to use their medication unchanged and regularly prior to and during the study. None of the subjects had a history of disease other than asthma, or used any other medication. Subjects with symptoms of a respiratory tract infection within 4 weeks prior to or during the study were excluded. The characteristics of the subjects studied are summarized in table 1 . The study was approved by the Hospital Medical Ethics Committee, and informed consent was given by all subjects.

\section{Design}

On a screening day, inclusion criteria were checked. Thereafter, the subjects attended the laboratory on two separate days, with an interval of at least 2 days (median

Table 1. - Characteristics of the subjects studied

\begin{tabular}{cccccc}
\hline $\begin{array}{l}\text { Subject } \\
\text { No. }\end{array}$ & Sex & $\begin{array}{c}\text { Age } \\
\text { yrs }\end{array}$ & $\begin{array}{c}\mathrm{FEV1}^{\#} \\
\text { \% }\end{array}$ & $\begin{array}{c}\text { PC2 } \\
\mathrm{mg} \cdot \mathrm{mL}^{-1}\end{array}$ & $\begin{array}{c}\text { Corticosteroid } \\
\text { medication }\end{array}$ \\
\hline 1 & $\mathrm{M}$ & 31 & 78 & 0.14 & \\
2 & $\mathrm{~F}$ & 23 & 83 & 0.16 & \\
3 & $\mathrm{~F}$ & 24 & 90 & 0.28 & \\
4 & $\mathrm{M}$ & 18 & 92 & 0.44 & \\
5 & $\mathrm{M}$ & 25 & 87 & 0.49 & \\
6 & $\mathrm{~F}$ & 26 & 93 & 0.61 & \\
7 & $\mathrm{~F}$ & 24 & 102 & 0.65 & \\
8 & $\mathrm{~F}$ & 19 & 102 & 1.01 & \\
9 & $\mathrm{M}$ & 22 & 86 & 1.54 & \\
10 & $\mathrm{M}$ & 25 & 88 & 2.83 & \\
11 & $\mathrm{M}$ & 26 & 108 & 3.27 & \\
12 & $\mathrm{M}$ & 24 & 102 & 4.70 & \\
13 & $\mathrm{~F}$ & 23 & 56 & 0.03 & $1600 \mu \mathrm{g}$ BUD \\
14 & $\mathrm{~F}$ & 20 & 44 & 0.06 & $400 \mu \mathrm{g}$ BDP \\
15 & $\mathrm{~F}$ & 21 & 49 & 0.11 & $800 \mu \mathrm{g}$ BUD \\
16 & $\mathrm{~F}$ & 21 & 83 & 0.23 & $200 \mu \mathrm{g}$ BDP \\
17 & $\mathrm{~F}$ & 34 & 85 & 0.32 & $1600 \mu \mathrm{g}$ BUD \\
18 & $\mathrm{M}$ & 21 & 66 & 0.43 & $2000 \mu \mathrm{g}$ BUD \\
19 & $\mathrm{M}$ & 27 & 79 & 0.88 & $1600 \mu \mathrm{g}$ BDP \\
20 & $\mathrm{M}$ & 23 & 60 & 1.00 & $1000 \mu \mathrm{g}$ BDP \\
21 & $\mathrm{~F}$ & 28 & 81 & 3.16 & $800 \mu \mathrm{g}$ BUD \\
\hline
\end{tabular}

All subjects received inhaled $\beta_{2}$-agonists on demand. \#: mean baseline value. M: male; F: female; $\mathrm{FEV}_{1}$ : forced expiratory volume in one second; PC20: provocative dose of histamine causing a $20 \%$ fall in $\mathrm{FEV}_{1}$; \% pred: percentage of predicted value; BDP: beclomethasone dipropionate; BUD: budesonide.
4 days). Sputum induction was performed on both occasions at the same time of day.

\section{Sputum induction}

Sputum induction was performed using a validated method [9] with some modifications. Sodium chloride aerosols $4.5 \%(\mathrm{w} / \mathrm{v})$ were generated at room temperature by an ultrasonic nebulizer (Ultraneb 2000; Devilbiss, Somerset, PA, USA) with a calibrated particle size (mass median aerodynamic diameter $4.5 \mu \mathrm{m}$ ), with the output set at maximal $\left(2.5 \mathrm{~mL} \cdot \mathrm{min}^{-1}\right)$. The aerosols were administered to the subjects through a $100 \mathrm{~cm}$ long tube with an internal diameter of $22 \mathrm{~mm}$, and were inhaled by mouth through a two-way valve (No. 2700; Hans-Rudolph, Kansas City, MO, USA), while the nose was clipped.

FEV1 was measured by standardized spirometry [14] before inhalation of the hypertonic saline aerosols, and whenever the subject felt uncomfortable during the sputum induction. For safety reasons, all subjects received salbutamol $400 \mu \mathrm{g}$ via a metered-dose inhaler (MDI) connected to an aerosol chamber. Aerosols were then inhaled in $5 \mathrm{~min}$ periods for a maximum of $30 \mathrm{~min}$. Following every period of hypertonic saline inhalation, subjects were asked to rinse their mouth and gargle their throat thoroughly with water. If necessary, the nose was blown. The subjects were then encouraged to cough and to expectorate sputum into a clean plastic container. The procedure was discontinued if an adequate amount of sputum was obtained (at least $2.5 \mathrm{~g}$ ) or if the subjects experienced any discomfort.

\section{Sputum processing}

The volume of the whole sputum sample was determined, and an equal volume of dithiothreitol $0.1 \%$ (Sputolysin; Calbiochem, La Jolla, CA, USA) was added [9]. The samples were gently mixed using a wide bore plastic pipette, and placed in a shaking water bath at $37^{\circ} \mathrm{C}$ for $15 \mathrm{~min}$ to ensure complete homogenization. The total cell count was measured in the group with moderateto-severe asthma using a standard haemocytometer. The homogenized sputum was centrifuged at $350 \times \mathrm{g}$ for 10 min. The supernatant was aspirated and stored at $-70^{\circ} \mathrm{C}$ pending analysis. The cell pellet was resuspended in 10 $\mathrm{mL}$ phosphate-buffered saline, filtered through a nylon gauze (pore size approximately $1 \mathrm{~mm}$ ), cytocentrifuged for $3 \mathrm{~min}$ at 1,500 rpm (Shandon cytocentrifuge 3; Shandon Southern Instruments, Sewickley, PA, USA), and stained with May-Grünwald-Giemsa [2]. In a subgroup of 18 samples, cell viability was checked by trypan blue exclusion, and appeared to be satisfactory with a mean (SEM) of 80 (3)\%. Differential cell counts were performed by counting at least 500 cells on one coded cytospin in a blind way by a qualified cytopathologist. Sputum samples containing more than $80 \%$ squamous cells were excluded from the analysis because of poor cytospin quality.

\section{Biochemical assays}

In sputum supernatant, albumin was assessed by rate nephelometric assay (Beckman, Brea, CA, USA), fibrinogen by enzyme-linked immunosorbent assay (ELISA) 
using polyclonal antibodies (generously donated by R. Bos, Gaubius Laboratory TNO-PG, Leiden, The Netherlands), IL- 8 by ELISA (Central Laboratory of The Netherlands Red Cross Blood Transfusion Service, Amsterdam, The Netherlands), and ECP by fluoroenzyme immunoassay (Pharmacia, Uppsala, Sweden).

\section{Analysis}

Cell differential counts were expressed as percentage of nonsquamous cells. Differences in cell counts and levels of soluble markers of inflammation between the two study days were analysed with Student's t-test for paired data, while differences in these parameters between the two groups were analysed with the Student's t-test for unpaired data. Differences were considered to be statistically significant at a p-value of 0.05 or less. Linear regression analysis was used to assess the relationship (r) between the percentage squamous cells (mean of Day 1 and Day 2) and the absolute difference in cellular and soluble parameters between Days 1 and 2 in each subject. Concentrations of soluble markers were logtransformed before analysis, because differences between the two study days were proportional to the mean value of these two days [16]. Repeatability was expressed as intraclass correlation coefficient $(\mathrm{R} i=$ between subject variance/(within+between subject variance)) [17], and as coefficient of repeatability $(\mathrm{CR}=2 \mathrm{SD}$ of the mean difference of repeated measurements) in percentage cells or in doubling concentrations [16]. The CR represented the limits of agreement within which $95 \%$ of the differences were expected to be. Unless otherwise stated, the data were expressed as mean $\pm \mathrm{SD}$, or as geometric mean $\pm \mathrm{SD}$ in doubling concentrations in case of log-transformation [17].

\section{Results}

There was no significant difference in age between the two groups. As expected, mean baseline FEV1 (mean \pm SD) differed significantly between patients with mild (92 \pm 9
$\%$ pred) and moderate-to-severe asthma ( $67 \pm 16 \%$ pred) $(\mathrm{p}<0.001) . \mathrm{PC}_{20}$ histamine (geometric mean \pm SD in doubling dose) was slightly but not significantly lower in the patients with moderate-to-severe asthma $(0.28 \pm 2.3$ $\left.\mathrm{mg} \cdot \mathrm{mL}^{-1}\right)$ as compared to the patients with mild asthma $\left(0.79 \pm 1.7 \mathrm{mg} \cdot \mathrm{mL}^{-1}\right)(\mathrm{p}=0.107)$. None of the subjects experienced discomfort during the sputum induction. All subjects were able to produce adequate amounts of sputum (range 2.6-10 g) for analysis. Sputum samples obtained from two subjects (Nos. 1 and 5) with mild asthma contained $>80 \%$ squamous cells on both study days, and were excluded from further analysis. Two samples from patients with moderate-to-severe asthma were not available for analysis of albumin, fibrinogen and IL-8.

The differential cell counts obtained from the subjects with mild and moderate-to-severe asthma separately, as well as from the two groups combined, are shown in table 2. Reproducibility was satisfactory for all nonsquamous cell types, in particular for eosinophils $(\mathrm{Ri}=$ $0.85)$. Because the percentage of ciliated epithelial cells from subjects with mild asthma differed between the two study days, these data were excluded from further analysis [16]. In addition, repeatability of cell counts $\mathrm{mL}^{-1}$ sputum were determined in the group with moderate-tosevere asthma for total cells $(\mathrm{Ri}=0.57)$, squamous cells $(\mathrm{Ri}$ $=0.17)$, bronchial epithelial cells $(\mathrm{Ri}=0.54)$, macrophages ( $R i=0.68)$, neutrophils $(R i=0.80)$, eosinophils $(R i=0.72)$, and lymphocytes $(\mathrm{Ri}=0.41)$. Good reproducibility was obtained for all fluid phase measurements, with an Ri ranging from 0.66 for IL- 8 to 0.88 for fibrinogen. The results of the soluble markers are summarized in table 2 and figure 2 .

The mean percentage of eosinophils was higher in the moderate-to-severe asthmatic patients as compared to the mild asthmatic patients $(\mathrm{p}=0.05)$ (table 2$)$. No other significant differences were observed in cellular or soluble markers (tables 2 and 3). The levels of sputum ECP appeared to be closely related to the levels of albumin $(\mathrm{r}=0.78 ; \mathrm{p}<0.001)$, and IL-8 ( $\mathrm{r}=0.63 ; \mathrm{p}=0.007)$ (fig. 3).

The mean percentage of squamous cells did not correlate with the difference between the two days in differential counts of any of the nonsquamous cells. Also, no

Table 2. - Repeatability of cellular markers in induced sputum

\begin{tabular}{|c|c|c|c|c|c|c|}
\hline & Squamous cells & Ciliated cells & Macrophages & Neutrophils & Eosinophils & Lymphocytes \\
\hline $\begin{array}{l}\text { Mild asthma } \\
\text { Day } 1 \% \\
\text { Day } 2 \%\end{array}$ & $\begin{array}{l}53 \pm 19 \\
40 \pm 19\end{array}$ & $\begin{array}{l}17 \pm 13 \\
12 \pm 9\end{array}$ & $\begin{array}{l}45 \pm 23 \\
40 \pm 21\end{array}$ & $\begin{array}{l}29 \pm 16 \\
39 \pm 21\end{array}$ & $\begin{array}{l}6.1 \pm 6.1 \\
6.1 \pm 7.4\end{array}$ & $\begin{array}{l}3.1 \pm 1.8 \\
2.4 \pm 0.9\end{array}$ \\
\hline $\begin{array}{l}\text { Difference p-value } \\
\mathrm{CR} \% \\
\mathrm{Ri}\end{array}$ & $\begin{array}{l}0.07 \\
40.2 \\
0.31\end{array}$ & $\begin{array}{l}0.01 \\
\text { ND } \\
\text { ND }\end{array}$ & $\begin{array}{l}0.48 \\
36.1 \\
0.68\end{array}$ & $\begin{array}{l}0.07 \\
31.2 \\
0.56\end{array}$ & $\begin{array}{l}0.99 \\
9.3 \\
0.79\end{array}$ & $\begin{array}{l}0.24 \\
3.7 \\
0.11\end{array}$ \\
\hline $\begin{array}{l}\text { Moderate-to-severe } \\
\text { Day } 1 \% \\
\text { Day } 2 \%\end{array}$ & $\begin{array}{l}\text { na } \\
39 \pm 16 \\
38 \pm 22\end{array}$ & $\begin{array}{l}13 \pm 8 \\
12 \pm 7\end{array}$ & $\begin{array}{l}38 \pm 12 \\
37 \pm 17\end{array}$ & $\begin{array}{l}28 \pm 14 \\
27 \pm 16\end{array}$ & $\begin{array}{l}14 \pm 11 \\
18 \pm 16\end{array}$ & $\begin{array}{l}6.4 \pm 6.2 \\
6.3 \pm 5.2\end{array}$ \\
\hline $\begin{array}{l}\text { Difference p-value } \\
\mathrm{CR} \% \\
\mathrm{Ri}\end{array}$ & $\begin{array}{l}0.93 \\
35.4 \\
0.62\end{array}$ & $\begin{array}{l}0.66 \\
19.2 \\
0.29\end{array}$ & $\begin{array}{l}0.83 \\
28.0 \\
0.56\end{array}$ & $\begin{array}{l}0.75 \\
27.3 \\
0.61\end{array}$ & $\begin{array}{l}0.13 \\
14.5 \\
0.84\end{array}$ & $\begin{array}{l}0.93 \\
9.6 \\
0.68\end{array}$ \\
\hline $\begin{array}{l}\text { Mild and severe as } \\
\text { Day } 1 \% \\
\text { Day } 2 \%\end{array}$ & $\begin{array}{r}\text { combined } \\
46 \pm 19 \\
39 \pm 20\end{array}$ & $\begin{array}{l}15 \pm 11 \\
12 \pm 8\end{array}$ & $\begin{array}{l}42 \pm 18 \\
39 \pm 19\end{array}$ & $\begin{array}{l}29 \pm 14 \\
33 \pm 19\end{array}$ & $\begin{array}{l}9.9 \pm 9.7 \\
12 \pm 14\end{array}$ & $\begin{array}{l}4.7 \pm 4.6 \\
4.2 \pm 4.2\end{array}$ \\
\hline $\begin{array}{l}\text { Difference p-value } \\
\mathrm{CR} \% \\
\mathrm{Ri}\end{array}$ & $\begin{array}{l}0.12 \\
39.3 \\
0.46\end{array}$ & $\begin{array}{l}0.07 \\
15.4 \\
0.64\end{array}$ & $\begin{array}{l}0.47 \\
31.2 \\
0.64\end{array}$ & $\begin{array}{l}0.20 \\
31.0 \\
0.57 \\
\end{array}$ & $\begin{array}{l}0.19 \\
12.4 \\
0.85\end{array}$ & $\begin{array}{l}0.80 \\
6.9 \\
0.76 \\
\end{array}$ \\
\hline
\end{tabular}

Values are presented as mean \pm SD. Differences between the two days are represented by p-value. Repeatability is expressed as coefficient of repeatability $\left(\mathrm{CR}_{\mathrm{R}}\right)$ in percentage cells and as intraclass correlation coefficient $(\mathrm{Ri})$. ND: not determined. 

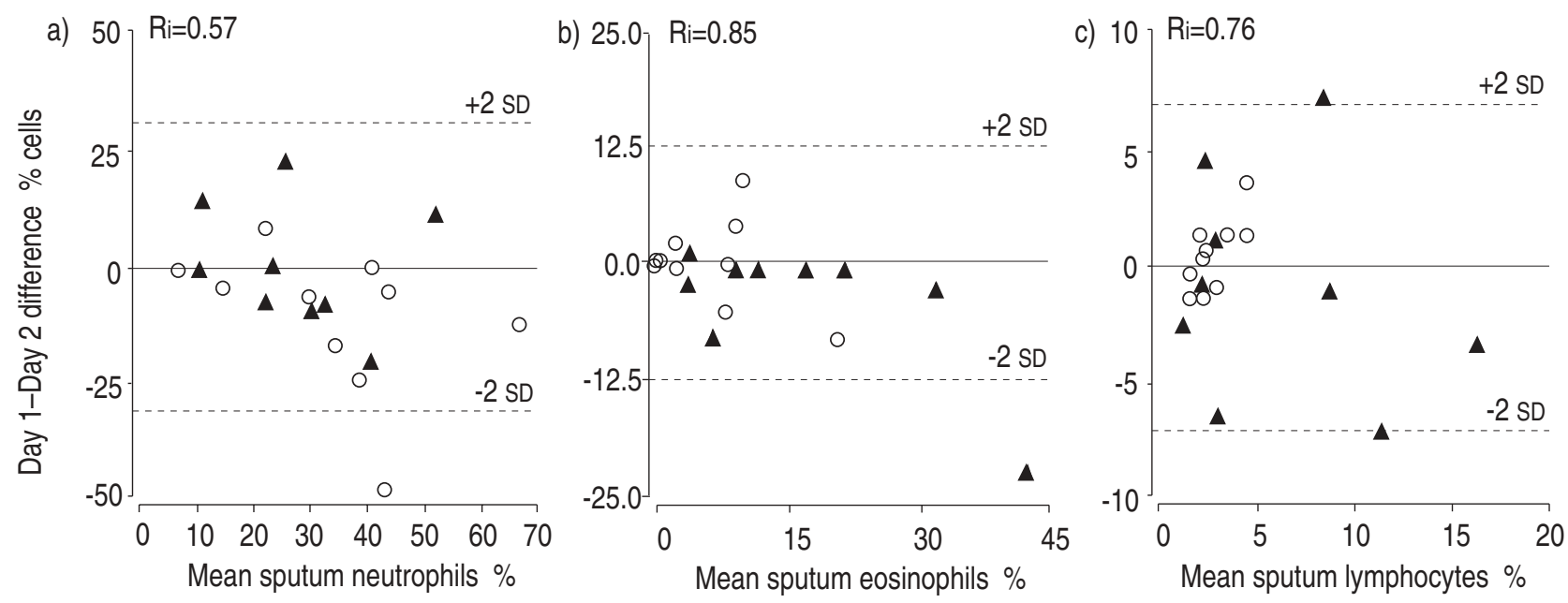

Fig. 1. - Repeatability of: a) neutrophils; b) eosinophils; and c) lymphocytes in induced sputum from the patients with mild ( $\bigcirc$ ) and moderate-to-severe asthma $(\mathbf{\Delta})$. The mean percentage of cells of each subject is plotted against the differences between Day 1 and Day 2 . The solid line represents the line of identity. The limits of agreement $(\mathrm{CR})$ for the whole group are represented by the broken lines (line of identity \pm 2 SD). $\mathrm{CR}_{\mathrm{R}}$ c coefficient of repeatability; Ri: intraclass correlation coefficient.
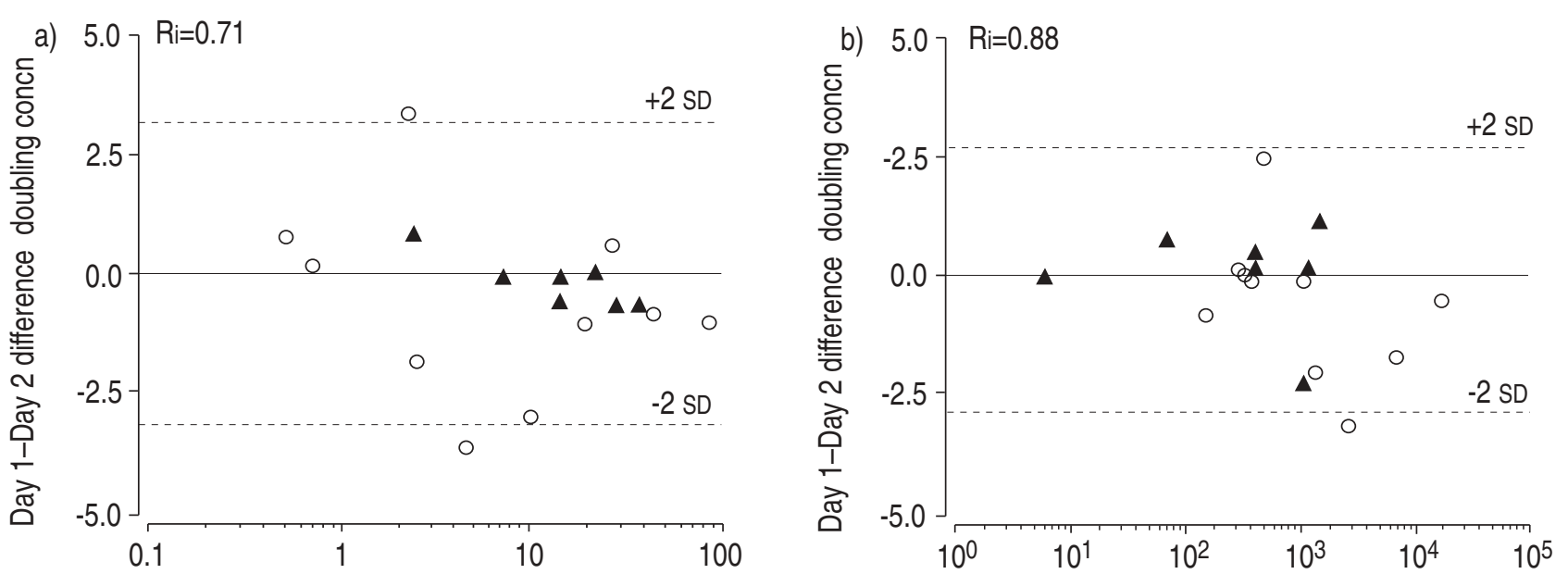

Geometric mean albumin concentration $10^{4} \mathrm{ng} \cdot \mathrm{mL}^{-1}$
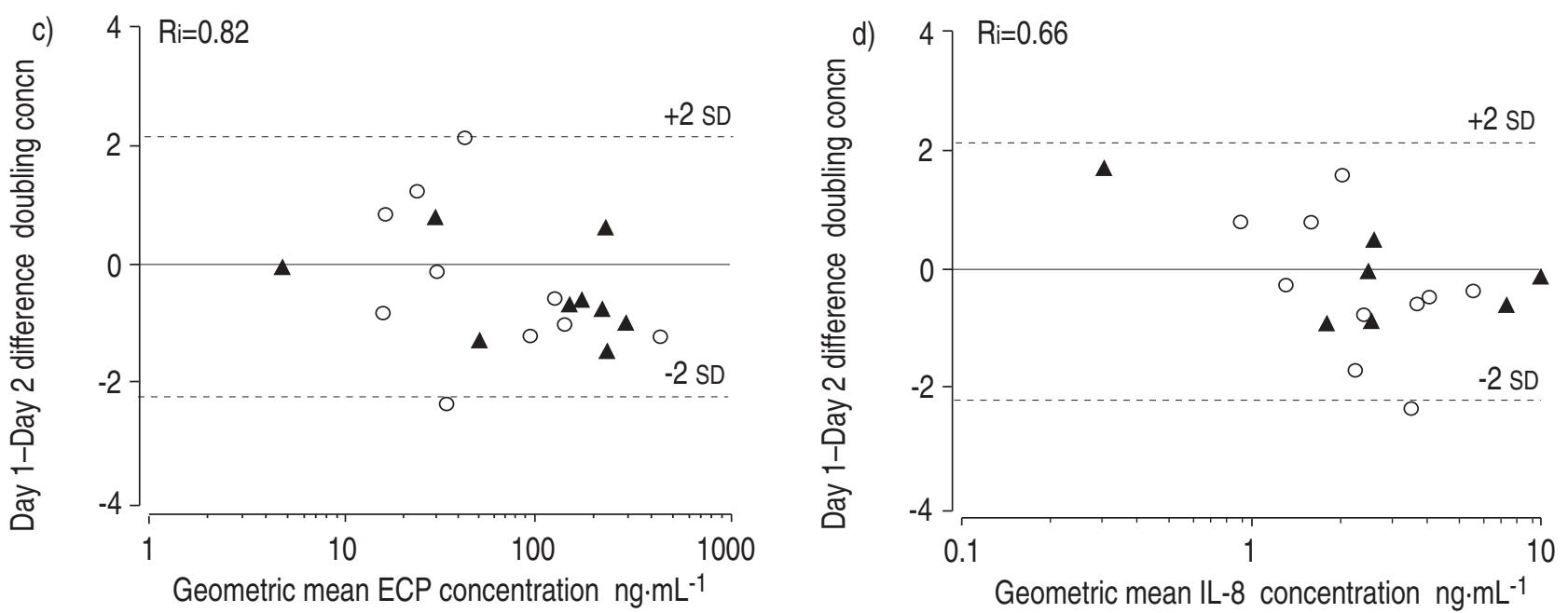

Fig. 2. - Repeatability of: a) albumin; b) fibrinogen; c) ECP; and d) IL-8 in induced sputum from the patients with mild (O) and moderate-tosevere asthma $(\boldsymbol{\Delta})$. The geometric mean concentration of each subject is plotted against the difference between Day 1 and Day 2 in doubling concentrations (concn). The solid line represents the line of identity. The limits of agreement (CR) for the whole group are represented by the broken lines (line of identity \pm SD in doubling concentrations). ECP: eosinophil cationic protein; IL-8: interleukin-8; CR: coefficient of repeatability; Ri: intraclass correlation coefficient. 
Table 3. - Repeatability of soluble markers in induced sputum

\begin{tabular}{|c|c|c|c|c|}
\hline & $\begin{array}{l}\text { Albumin } \\
10^{4} \mathrm{ng} \cdot \mathrm{mL}^{-1}\end{array}$ & $\begin{array}{c}\text { Fibrinogen } \\
\mathrm{ng} \cdot \mathrm{mL}^{-1}\end{array}$ & $\begin{array}{c}\mathrm{IL}-8 \\
\mathrm{ng} \cdot \mathrm{mL}^{-1}\end{array}$ & $\begin{array}{c}\mathrm{ECP} \\
\mathrm{ng} \cdot \mathrm{mL}^{-1}\end{array}$ \\
\hline \multicolumn{5}{|l|}{ Mild asthma } \\
\hline Day 1 & $5.2 \pm 2.4$ & $831 \pm 2$ & $2.1 \pm 0.7$ & $49 \pm 1.4$ \\
\hline Day 2 & $8.4 \pm 2.9$ & $1288 \pm 2.6$ & $2.7 \pm 1.2$ & $60 \pm 1.9$ \\
\hline Difference $p$-value & 0.32 & 0.23 & 0.07 & 0.50 \\
\hline $\mathrm{CR}_{\mathrm{R}}$ & 4.1 & 3.1 & 2.4 & 2.7 \\
\hline $\mathrm{Ri}$ & 0.72 & 0.77 & 0.30 & 0.69 \\
\hline \multicolumn{5}{|c|}{ Moderate-to-severe asthma } \\
\hline Day 1 & $13 \pm 1.1$ & $184 \pm 3.0$ & $2.5 \pm 1.4$ & $91 \pm 1.9$ \\
\hline Day 2 & $14 \pm 1.6$ & $168 \pm 3.1$ & $2.5 \pm 2.0$ & $107 \pm 2.2$ \\
\hline Difference $p$-value & 0.38 & 0.78 & 0.99 & 0.17 \\
\hline $\mathrm{CR}$ & 1.0 & 2.2 & 1.8 & 1.6 \\
\hline $\mathrm{Ri}$ & 0.92 & 0.94 & 0.87 & 0.92 \\
\hline \multicolumn{5}{|c|}{ Mild and severe asthma combined } \\
\hline Day 1 & $7.5 \pm 2.1$ & $445 \pm 2.6$ & $2.3 \pm 1.0$ & $62 \pm 1.7$ \\
\hline Day 2 & $10 \pm 2.5$ & $556 \pm 3.1$ & $2.6 \pm 1.5$ & $79 \pm 2.0$ \\
\hline Difference $p$-value & e 0.23 & 0.36 & 0.45 & 0.19 \\
\hline $\mathrm{CR}$ & 3.2 & 2.8 & 2.2 & 1.1 \\
\hline $\mathrm{Ri}$ & 0.71 & 0.88 & 0.66 & 0.82 \\
\hline
\end{tabular}

Values are presented as mean \pm SD in doubling concentrations. Differences between the two days are represented by p-value. repeatability is expressed as coefficient of repeatability $(\mathrm{CR})$ in doubling concentrations and as intraclass correlation coefficient (Ri). IL-8: interleukin-8; ECP: eosinophil cationic protein.
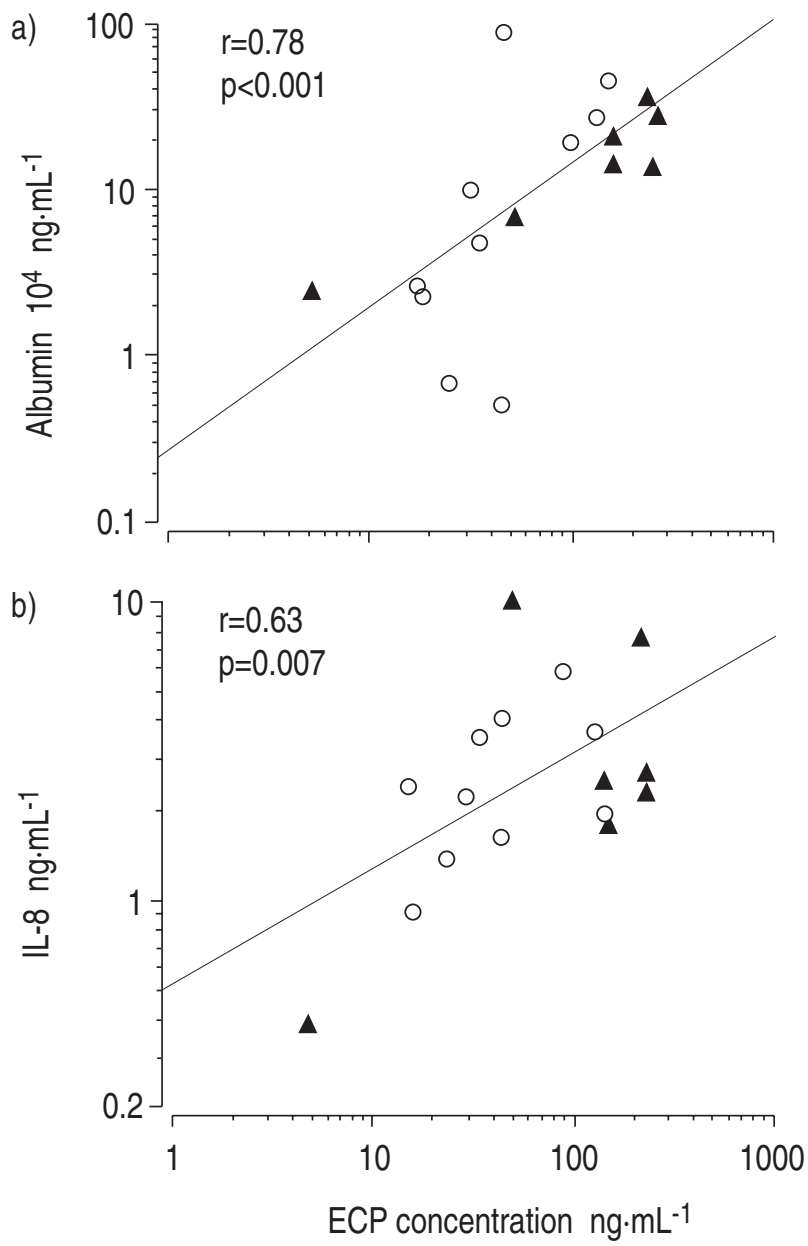

Fig. 3. - Correlation of geometric mean (of Day 1 and Day 2) levels of sputum ECP and: a) sputum albumin; and b) sputum IL-8 from the patients with mild asthma $(\bigcirc)$ and moderate-to-severe asthma $(\boldsymbol{\Delta})$. significant correlation was observed between mean percentage of squamous cells and the difference in fluid phase measurements between Days 1 and 2 in each subject.

\section{Discussion}

This study shows that reproducible quantitative measurements of cellular and soluble markers of asthmatic airway inflammation can be obtained in induced sputum from patients with mild and moderate-to-severe asthma. The results of this study imply that the "whole sputum sample" technique is a reliable, noninvasive method that is potentially useful for monitoring inflammatory processes in the airways in clinical asthma studies.

The present study is the first showing good reproducibility of quantitative analysis of cells and soluble markers of inflammation in entire sputum samples from asthmatic patients. In earlier studies, adequate reproducibility has been shown for the "selected sample" or "plug" method $[1,18-20]$. Sputum plugs from asthmatic patients who produced sputum spontaneously were studied by GiBson et al. [18]. They showed high reproducibility of differential cell counts in sputum samples from the same patients on two consecutive days. The inability of most asthmatic patients to produce sputum spontaneously, especially when asthma is well-controlled, was, however, a major drawback of this method. PIN et al. [1] were first to introduce the technique of sputum induction by inhalation of nebulized hypertonic saline to study airway inflammation in asthma. They demonstrated that this technique offered good reproducibility for differential cell counts of neutrophils $(\mathrm{R} i=0.73)$, eosinophils $(\mathrm{Ri}=0.80)$, and macrophages $(\mathrm{Ri}=0.71)$ when "selected sputum plugs" were analysed. Recently, the same authors have reported comparable repeatability for several fluid phase measurements using the same technique [20].

It has been argued that microscopic selection of sputum plugs from the expectorated sample is essential to ensure that only specimens representative of the subglottic area, rather than a mixture including saliva, were selected for analysis [18]. Selection of plugs, however, could influence cell counts and levels of inflammatory protein [9]. In addition, cell and protein content of sputum plugs might not necessarily be representative of airway lining fluid [9]. Therefore, analysis of the entire induced sputum sample has been suggested as a method to overcome these problems. Preliminary reproducibility data of measurements in entire sputum samples were less promising $[21,22]$, possibly due to differences in methodological procedures.

In the present study, particular attention was paid to methodological aspects. The study subjects were optimally controlled, with no symptoms of respiratory infections, and unaltered medication usage. Sputum induction was performed by a standardized protocol, at the same time of day. Salivary contamination of the samples was minimized by instructing the patients to rinse their mouth and gargle their throat meticulously before expectoration. If, despite these measures, the samples contained more than $80 \%$ squamous cells, they were excluded from 
analysis of both cellular and soluble markers. Although intra- and interobserver variability in differential cell counting of cytospins has been reported to be negligible [8], Efthimiadis et al. [23] recently reported an increasing intra- and interobserver variability in cell counting concomitant with increasing squamous cell contamination. This phenomenon does not seem to have played a major role in the present study, considering the high intraclass correlation coefficient of the eosinophil cell counts. More importantly, the mean percentage of squamous cells in sputum was not related to the absolute difference in inflammatory cell counts or in levels of soluble markers between the two study days.

Although repeatability of measurements was satisfactory for both groups of patients with mild and moderate-to-severe asthma, reproducibility seemed slightly better in the latter group. A possible explanation might be that fluctuations in airway inflammation are mitigated by anti-inflammatory treatment in this group, resulting in better repeatability. An alternative explanation could be that subjects with more severe asthma are more familiar with sputum production, and are able to expectorate more smoothly with less variability in oropharyngeal contamination.

This study was not designed to investigate differences in sputum parameters between mild and moderate-tosevere atopic asthma. Nevertheless, numbers of eosinophils were significantly higher in the latter group. This extends the findings of other investigators, who observed increased numbers of eosinophils in sputum from patients with asthma as compared to normal subjects [1, 9] or patients with chronic bronchitis [18], and confirms that eosinophil numbers in induced sputum are related to the severity of airway inflammation in asthma. In addition, the close correlation between ECP levels and other soluble markers suggests the reliability of the method.

The clinical implication of the present study seems to be that analysis of sputum induced and processed according to the "whole sample" method is a reliable and reproducible method to estimate the severity of airway inflammation in a wide range of asthmatic patients. Since almost all patients were able to expectorate evaluable sputum samples, this method might be a preferable alternative to more invasive methods, such as fibreoptic bronchoscopy with bronchoalveolar lavage (BAL) or bronchial biopsy; the more so, since a close relationship has recently been shown between counts of inflammatory cells in induced sputum on the one hand and in bronchial wash, BAL and mucosal biopsies on the other [4-6]. Induced sputum could, in fact, provide a valuable means to evaluate the effects of therapeutic intervention in management of clinical asthma.

In conclusion, this study has confirmed that sputum induction is a simple and safe noninvasive technique in mild and moderate-to-severe asthmatic patients. By processing and analysing the whole sputum sample, satisfactorily reproducible data can be obtained for cellular and soluble markers. Oropharyngeal contamination is a potentially disturbing factor, but does not seem to substantially influence the reproducibility of the measurements. Hence, induced sputum seems to be a valuable method to monitor asthmatic inflammation in research and clinical practice.
Acknowledgement: The authors wish to thank G.G. Wendt, Department of Cytopathology, for counting the cytospins.

\section{References}

1. Pin I, Gibson PG, Kolendowicz R, et al. Use of induced sputum cell counts to investigate airway inflammation in asthma. Thorax 1992; 47: 25-29.

2. Popov T, Gottschalk R, Kolendowicz R, Dolovich J, Powers P, Hargreave FE. The evaluation of a cell dispersion method of sputum examination. Clin Exp Allergy 1994; 24: 778-783.

3. Popov T, Pizzichini MMM, Pizzichini E, et al. Some technical factors influencing the induction of sputum for cell analysis. Eur Respir J 1995; 8: 559-565.

4. Fahy JV, Wong H, Liu J, Boushey HA. Comparison of samples collected by sputum induction and bronchoscopy from asthmatic and healthy subjects. Am J Respir Crit Care Med 1995; 152: 53-58.

5. Grootendorst DC, Sont JK, van der Marel A, et al. Cellular markers of airway inflammation in asthma: induced sputum versus bronchial biopsies, bronchial wash (BW) and bronchoalveolar lavage (BAL) (Abstract). Eur Respir $J$ 1995; 8: 7s.

6. Maestrelli P, Saetta M, Di Stefano A, et al. Comparison of leukocyte counts in sputum, bronchial biopsies, and bronchoalveolar lavage. Am J Respir Crit Care Med 1995; 152: 1926-1931.

7. O'Byrne PM, Hargreave FE. Noninvasive monitoring of airway inflammation. Am J Respir Crit Care Med 1994; 150: S100-S102.

8. Iredale MJ, Wanklyn SAR, Phillips IP, Krausz T, Ind PW. Noninvasive assessment of bronchial inflammation in asthma: no correlation between eosinophilia of induced sputum and bronchial responsiveness to inhaled hypertonic saline. Clin Exp Allergy 1994; 24: 940-945.

9. Fahy JV, Liu J, Wong H, Boushey HA. Cellular and biochemical analysis of induced sputum from asthmatic and from healthy subjects. Am Rev Respir Dis 1993; 147: 1126-1131.

10. Gelder CM, Thomas PS, Yates DH, Adcock IM, Morrison JFJ, Barnes PJ. Cytokine expression in normal, atopic, and asthmatic subjects using the combination of sputum induction and the polymerase chain reaction. Thorax 1995; 50: 1033-1037.

11. Erger RA, Casale TB. Interleukin-8 is a potent mediator of eosinophil chemotaxis through endothelium and epithelium. Am J Physiol 1995; 268: L117-L122.

12. Adelroth E, Rosenhall L, Johansson S, Linden M, Venge P. Inflammatory cells and eosinophilic activity in asthmatics investigated by bronchoalveolar lavage. Am Rev Respir Dis 1990; 142: 91-99.

13. National Heart Lung and Blood Institute. International consensus report on diagnosis and treatment of asthma. Eur Respir J 1992; 5: 601-641.

14. Quanjer PH, Tammeling GJ, Cotes JE, Pedersen OF, Peslin R, Yernault J. Lung volumes and forced ventilatory flows. Eur Respir J 1993; 6 (Suppl. 16): 5-40.

15. Sterk PJ, Fabbri LM, Quanjer PH, et al. Airway responsiveness. Standardized challenge testing with pharmacological, physical and sensitizing stimuli in adults. Eur Respir J 1993; 6 (Suppl. 16): 53-83.

16. Bland JM, Altman DG. Statistical methods for assessing agreement between two methods of clinical measurements. Lancet 1986; i: 307-310. 
17. Chinn S. Repeatability and method comparison. Thorax 1991; 46: 454-456.

18. Gibson PG, Girgis-Gabardo A, Morris MM, et al. Cellular characteristics of sputum from patients with asthma and chronic bronchitis. Thorax 1989; 44: 693-699.

19. Spanevello A, Sharara AM, Migliori GB, Bridge P, Neri M, Ind PW. Reproducibility of induced sputum cell counts in patients with stable asthma (Abstract). Eur Respir J 1995; 19: 138s.

20. Pizzichini E, Pizzichini MMM, Efthimiades A, Evans S, Morris MM, Squillace D, Gleich GJ, Dolovich J, Hargreave FE. Indices of airway inflammation in induced sputum: reproducibility and viability of cell and fluid-phase measurements. Am J Respir Crit Care Med 1996; 154: 308-317.

21. Fahy JV, Lui J, Boushey HA. Reproducibility of measurements made in induced sputum from asthmatic subjects (Abstract). Am J Respir Crit Care Med 1995; 151: A384.

22. Bellia V, Mirabella F, Scichilone N, et al. Reproducibility of biochemical measurements in induced sputum (Abstract). Am J Respir Crit Care Med 1995; 151: A386.

23. Efthimiadis A, Pizzichini MMM, Pizzichini E, et al. The influence of cell viability and squamous epithelial cell contamination on the reliability of sputum differential cell counts (Abstract). Am J Respir Crit Care Med 1995; 151: A384. 